\title{
EDITORIAL
}

\section{The End of a Decade and the Dawn of a Climate Resistance}

\section{INTRODUCTION}

As this editorial is being written, the decade is drawing to an end. Or, perhaps more aptly, the decade is roiling to an end. Hong Kong and Chile are rocked by protests. ${ }^{1}$ Australia and the Amazon are burning. ${ }^{2}$ The President of the United States has been impeached. ${ }^{3}$ The United Kingdom is tearing away from the European Union (EU). ${ }^{4}$ India is debating its identity. ${ }^{5}$ Egypt and Ethiopia are locked in protracted negotiations over the future of the Nile. ${ }^{6}$ Children all over the world are skipping school and standing up to fight for a future where their world is not ravaged by unchecked climate change. $^{7}$

It has been an eventful period for the rule of law and for ongoing efforts to curb environmental degradation. It was the decade that saw the launch of Transnational Environmental Law $(T E L)^{8}$ in response to a growing panoply of global and transnational environmental problems that demanded innovative thinking, new modes of cooperation and, above all else, persistent legal development. As time progressed, $T E L$ bore witness to and advanced conversations around the emerging environmental

1 R. Hughes, 'The Year in Protests: From Chile to Lebanon, What Happened Next?', BBC News, 22 Dec. 2019, available at: https://www.bbc.com/news/world-50822363?intlink_from_url=https://www.bbc. com/news/world/latin_america\&link_location=live-reporting-story.

2 'Australia Fires: "Not Much Left" of Town after Ravaged by Bushfire', BBC News, 23 Dec. 2019, available at: https://www.bbc.com/news/world-australia-50885772; 'Is Climate Change to Blame for Australia's Bushfires?', BBC News, 11 Nov. 2019, available at: https:/www.bbc.com/news/world-australia-50341210.

3 R. Elving, 'Trump is Impeached, but There's No Endgame in Sight', NPR, 21 Dec. 2019, available at: https:/www.npr.org/2019/12/21/790313280/trump-is-impeached-but-theres-no-endgame-in-sight.

4 'Brexit: MPs Voting on Johnson's Brexit Bill', BBC News, 20 Dec. 2019, available at: https://www.bbc. com/news/uk-politics-50854323.

5 'Jharkland Election Results: BJP Concedes Defeat Amid Citizenship Row', BBC News, 23 Dec. 2019 , available at: https:/www.bbc.com/news/world-asia-india-50888666.

6 I.K. Harb, 'River of the Damned', Foreign Policy, 15 Nov. 2019, available at: https://foreignpolicy.com/ 2019/11/15/river-of-the-dammed.

7 M. Carlisle, 'Millions Around the World Strike on Black Friday for Action on Climate Change', Time, 29 Nov. 2019, available at: https://time.com/5741593/black-friday-climate-strike.

8 V. Heyvaert \& T.F.M. Etty, 'Introducing Transnational Environmental Law' (2012) 1(1) Transnational Environmental Law, pp. 1-11. 
rights revolution, ${ }^{9}$ the spread of global environmental constitutionalism, ${ }^{10}$ the maturing of global environmental law, ${ }^{11}$ and the tragedies and triumphs of the evolving field of climate law. ${ }^{12}$

As the decade ends, despite meaningful progress in cultivating legal strategies to address environmental challenges, we find ourselves facing mounting challenges with regard to the rule of law and environmental degradation, particularly climate change.

Globally, the rule of law is under pressure. The great powers are grappling for influence and supremacy. ${ }^{13}$ Populism and nationalism have surged worldwide, prompting mounting fears that democracy is in decline and the stability of the rule of law is precarious. ${ }^{14}$ Notably, between 1990 and 2018, the number of populist leaders increased by a 'remarkable fivefold, from four to 20 '15 and, by 2019 , populist leaders ruled the world's four most populous democracies. ${ }^{16}$ The swelling populist and nationalist movements challenge already fragile cooperative international and transnational institutions and erode a shared sense of purpose and understanding of the rule of law and its operation. ${ }^{17}$ Moreover, there is widespread concern that the rise of populism and

9 P. Villavicencio Calzadilla \& L.J. Kotzé, 'Living in Harmony with Nature? A Critical Appraisal of the Rights of Mother Earth in Bolivia' (2018) 7(3) Transnational Environmental Law, pp. 397-424; S. Adelman \& B. Lewis, 'Symposium Foreword: Rights-Based Approaches to Climate Change' (2018) 7(1) Transnational Environmental Law, pp. 9-15; S. Borràs, 'New Transitions from Human Rights to the Environment to the Rights of Nature' (2016) 5(1) Transnational Environmental Law, pp. 113-43.

10 L.J. Kotzé, 'Arguing Global Environmental Constitutionalism' (2012) 1(1) Transnational Environmental Law, pp. 199-233; L.J. Kotzé, 'A Global Environmental Constitution for the Anthropocene?' (2019) 8(1) Transnational Environmental Law, pp. 11-33; D. Kysar, 'Global Environmental Constitutionalism: Getting There from Here' (2012) 1(1) Transnational Environmental Law, pp. 83-94.

11 E. Morgera, 'Symposium Foreword: Advancing the Research Agenda on Global Environmental Law' (2019) 8(3) Transnational Environmental Law, pp. 399-403; R.E. Kim \& K. Bosselmann, 'International Environmental Law in the Anthropocene: Towards a Purposive System of Multilateral Environmental Agreements' (2013) 2(2) Transnational Environmental Law, pp. 285-309.

12 T.F.M. Etty, V. Heyvaert, et al., 'Transnational Climate Law' (2018) 7(2) Transnational Environmental Law, pp. 191-200; K.W. Abbott, 'Strengthening the Transnational Regime Complex for Climate Change' (2014) 3(1) Transnational Environmental Law, pp. 57-88.

13 See, e.g., T. Wright, 'The Return to Great-Power Rivalry was Inevitable', The Atlantic, 12 Sept. 2018, available at: https://www.brookings.edu/opinions/the-return-to-great-power-rivalry-was-inevitable; L. Diamond, 'Democracy in Decline', Foreign Affairs, July/Aug. 2016, available at: https://www.foreignaffairs.com/articles/world/2016-06-13/democracy-decline.

14 See N. Lace, 'Populism and the Rule of Law', LSE Working Paper 28, Jan. 2019, available at: https://www.lse.ac.uk/III; World Justice Project, 'WJP Rule of Law Index 2019: Global Press Release, Rule of Law Continues Negative Slide Worldwide', 27 Feb. 2019, available at: https:/worldjusticeproject.org/news/wjp-rule-law-index-2019-global-press-release ('The new WJP Rule of Law Index scores show that more countries declined than improved in overall rule of law performance for the second year in a row, continuing a negative slide toward weaker rule of law around the world').

15 J. Kyle \& L. Gultchin, 'Populists in Power Around the World', Tony Blair Institute for Global Change, 17 Nov. 2018, available at: https://institute.global/insight/renewing-centre/populists-power-around-world.

16 These include Narendra Modi in India, Donald Trump in the United States, Joko Widodo in Indonesia, and Jair Bolsonaro in Brazil.

17 See, e.g., President Donald J. Trump, Statement by President Trump on the Paris Climate Accord, 1 June 2017, available at: https://www.whitehouse.gov/briefings-statements/statement-president-trump-parisclimate-accord [https://perma.cc/U9YF-9792]; 'Amazon Rainforest Belongs to Brazil, Says Jair Bolsonaro’, BBC News, 24 Sept. 2019, available at: https:/www.bbc.co.uk/news/world-latin-america49815731; J. Dalton, 'Amazon Fires: Bolsonaro Rages at "Colonial” G7 Leaders over £16 Million Aid Deal to Fight Brazil Blazes', The Independent, 26 Aug. 2019, available at: https://www.independent.co.uk/news/world/americas/amazon-fires-bolsonaro-brazil-g7-summit-aid-deal-a9079586.html. 
nationalism poses particular threats to environmental law ${ }^{18}$ and hinders the development of the environmental rule of law. ${ }^{19}$

Shared understandings, whether of the rule of law or other foundational values of society, are necessarily tenuous and evolving. Equally, instabilities in the international system are inevitable. The deepening of these fluxes and the resulting volatilities, however, now intersect with and determine in part how we respond to the incontrovertibly global and inescapably determinative crisis of climate change. Indeed, despite 30 years of growing awareness, cooperation, and legal development, the climate crisis continues to escalate. Drawing on the scientific consensus articulated by the Intergovernmental Panel on Climate Change (IPCC), the United Nations (UN) has declared that we have just over a decade within which to act to limit greenhouse gas (GHG) emissions so as to avert the worst effects of climate change. ${ }^{20}$ Worldwide, intensifying patterns of climate change put pressure on human and natural systems, creating a cascading collection of social, political, and economic challenges.

Even as populism, nationalism, and great power politics intensify, and even as efforts to limit climate change face mounting challenges at every level, there is a surge of energy and efforts pushing back against the erosion of democracy and cooperative will, and clamouring for a strengthening and thickening of the rule of law around climate change. Climate law, in fact, is emerging as one of the most dynamic and important sites of legal and normative innovation for the coming decade. From local ${ }^{21}$ and national lawmaking, ${ }^{22}$ to novel litigation strategies, ${ }^{23}$ to burgeoning transnational social movements, ${ }^{24}$ to ongoing efforts to shape a more effective and equitable system of international climate law, 'the compelling nature of climate change as an existential

18 B.J. Preston, 'The End of Enlightened Environmental Law?' (2019) 31(3) Journal of Environmental Law, pp. 399-411; E. Fisher, 'Unearthing the Relationship Between Environmental Law and Populism' (2019) 31(3) Journal of Environmental Law, pp. 383-7.

19 UN Environmental Programme Res. $27 / 9$ (18-22 Feb. 2013), 'Advancing Justice, Governance and Law for Environmental Sustainability’, UN Doc. UNEP/GC.27/17, available at: https://wedocs.unep.org/bitstream/handle/20.500.11822/12221/Governing \%20Council\%20Decision \%2027-2.pdf? sequence=1\& isAllowed $=y$.

20 UN General Assembly, 'Only 11 Years Left to Prevent Irreversible Damage from Climate Change, Speakers Warn during General Assembly High-Level Meeting', GA/12131, 28 Mar. 2019, available at: https://www.un.org/press/en/2019/ga12131.doc.htm.

21 See, e.g., New York Climate Leadership and Community Protection Act, S6599, A8429, 2019-20 Reg. Sess. (N.Y. 2019); O. Milman et al., 'The Fight Against Climate Change: Four Cities Leading the Way in the Trump Era', The Guardian, 12 June 2017, available at: https://www.theguardian.com/cities/2017/ jun/12/climate-change-trump-new-york-city-san-francisco-houston-miami [https://perma.cc/6JPT-XXWF].

22 L. Wamsley, 'New Zealand Commits to Being Carbon Neutral by 2050 - With a Big Loophole', NPR, 7 Nov. 2019, available at: https://www.npr.org/2019/11/07/777259573/new-zealand-commits-tobeing-carbon-neutral-by-2050-with-a-big-loophole.

23 See, e.g., United Nations Human Rights, Office of the High Commissioner, 'Bachelet Welcomes Top Court's Landmark Decision to Protect Human Rights from Climate Change', 20 Dec. 2019, available at: https://www.ohchr.org/EN/NewsEvents/Pages/DisplayNews.aspx?NewsID=25450\&LangID=E; Press Release, 'Our Children's Trust, America's Youth File Landmark Climate Lawsuit Against U.S. Government and President', 12 Aug. 2015, available at: https://static1.squarespace.com/static/ 571d109b04426270152febe0/t/576c6e11ebbd1aee23f5f77e/1466723857447/15.08.12FederalClimate LawsuitPressRelease+\%281\%29.pdf.

24 C. Du Cann, 'Extinction Rebellion is Creating a New Narrative of the Climate Crisis', The New York Times, 28 Oct. 2019, available at: https://www.nytimes.com/2019/10/28/opinion/extinction-rebellionlondon.html; I. Irfan, 'Greta Thunberg is Leading Kids and Adults from 150 Countries in a Massive 
risk and the failure of our institutions to address it, in the face of a mountain of evidence $^{, 25}$ are spawning various efforts to respond to the mounting crisis.

It is this dynamism and innovation that this issue of TEL explores. The issue begins with a collection of Symposium articles that examine the 'current state of climate litigation, its implications and future prospects', ${ }^{26}$ before turning to a case note that meticulously unpacks the strategies, strengths, and weaknesses of one particularly high-profile ongoing climate case. ${ }^{27}$ Finally, the issue concludes with an article that reveals the extent to which the Paris Agreement ${ }^{28}$ simultaneously advances and constrains thinking on collective and individual obligations in international law. ${ }^{29}$ Collectively, these pieces offer insight into the rich and evolving landscape that is climate law.

\section{LITIGATION: THE FRONTLINE OF CLIMATE RESISTANCE}

This issue of TEL begins with a Symposium Collection emanating from a 2018 workshop at the Aarhus University Department of Law (Denmark), which brought together academics and practitioners to explore trends in climate change litigation. As these articles demonstrate, the courts have been a steady driving force in shaping the emerging rule of law around climate change, with the number and variety of climate change-related lawsuits that have been filed around the world surging in recent years. ${ }^{30}$ While characterizations of the patterns of climate litigation vary, recent trends suggest that we have entered a new wave of litigation in terms of both strategy and the transnational diffusion of litigation tactics. The cases target a variety of defendants, namely governments and corporations, including the largest global GHG emitters, collectively referred to as the "carbon majors'. ${ }^{11}$ These cases are being brought by non-profit organizations, states, cities, and increasingly by corporate investors, shareholders, and employees. As Mitkidis and Valkanou explain in their Foreword to the Symposium, the pieces in this collection 'deliver novel perspectives on the phenomenon

Friday Climate Strike', Vox, 20 Sept. 2019, available at: https://www.vox.com/2019/9/17/20864740/ greta-thunberg-youth-climate-strike-fridays-future.

S. Hecht, 'UCLA Law's Ann Carlson Interviewed on CBS's 60 Minutes Discussing Juliana v. U.S., Landmark Climate Change Lawsuit', 6 Mar. 2019, Legal Planet, available at: https://legal-planet.org/ 2019/03/06/ucla-laws-ann-carlson-interviewed-on-cbss-60-minutes-discussing-juliana-v-u-s-landmarkclimate-change-lawsuit [https://perma.cc/7NQD-WQ8H].

26 K. Mitkidis \& T.N. Valkanou, 'Climate Change Litigation: Trends, Policy Implications and the Way Forward' (2020) 9(1) Transnational Environmental Law, pp. 11-16, at 12.

27 G. Winter, 'Armando Carvalho and Others v. EU: Invoking Human Rights and the Paris Agreement for Better Climate Protection Legislation' (2020) 9(1) Transnational Environmental Law, pp. 137-64.

28 Paris (France), 12 Dec. 2015, in force 4 Nov. 2016, available at: http://unfccc.int/paris_agreement/items/ 9485.php.

29 A. Zahar, 'Collective Obligation and Individual Ambition in the Paris Agreement' (2020) 9(1) Transnational Environmental Law, pp. 165-88.

30 J. Setzer \& R. Byrnes, 'Global Trends in Climate Change Litigation: 2019 Snapshot', July 2019, available at: http://www.lse.ac.uk/GranthamInstitute/wp-content/uploads/2019/07/GRI_Global-trends-in-climatechange-litigation-2019-snapshot-2.pdf.

31 R. Heede, 'Tracing Anthropogenic Carbon Dioxide and Methane Emissions to Fossil Fuel and Cement Producers, 1854-2010’ (2014) 122(1) Climatic Change, pp. 229-41. 
[of climate litigation], unveiling new areas of interest, both intellectual and geographical', identifying 'gaps in existing legal scholarship', and revealing the need for expanded study of the plethora of questions to which the burgeoning body of climate litigation gives rise. ${ }^{32}$ In the five articles in this Symposium Collection the authors explore topics as varied as the interaction between international and domestic climate change law, the complex interplay between climate law and politics, trends in climate litigation in the Global South, and the growth and variety of climate litigation cases in financial markets. Together, these articles deepen our understanding of the expanding contours of an area of law that will continue to be an important site of legal interest, energy, and innovation in the coming years.

Complementing the Symposium articles is a unique and useful contribution from Gerd Winter. ${ }^{33}$ Winter's case note shifts the focus from patterns and prospects in climate litigation to the intricacies of one significant climate case sub judice. In this midstream analysis, Winter discusses the case of Carvalho and Others v. European Union, ${ }^{34}$ in which the applicants filed a claim before the EU General Court maintaining that EU law fails to limit GHG emissions as strictly as is required by EU human rights and international law. In this case, which amounts to a full-scale legal challenge to the adequacy of EU climate law, ten families from the EU, Kenya, and Fiji, who are engaged in agriculture and tourism-based businesses, claim that their livelihoods and well-being are directly affected by climate change and that EU law fails adequately to limit GHG emissions. As Winter describes, 'the application attacks the Union for insufficient environmental protection', ${ }^{35}$ arguing that the suite of three existing EU climate laws - the Emissions Trading Directive, ${ }^{36}$ the Climate Action Regulation, ${ }^{37}$ and the Land Use, Land-Use Change and Forestry Regulation ${ }^{38}$ - which set an overall target of reducing the EU's GHG emissions by 40\% below 1990 levels by 2030, is inadequately ambitious and incompatible with rights and obligations set out by the Charter of Fundamental Rights of the $\mathrm{EU}^{39}$ and the Paris Agreement. ${ }^{40}$

32 Mitkidis \& Valkanou, n. 26 above, pp. 15-6.

33 N. 27 above.

34 Case T-330/18, Carvalho and Others v. European Parliament and Council of the European Union, ECLI:EUT:2019:324.

35 Winter, n. 27 above.

36 Directive (EU) 2018/410 amending Directive 2003/87/EC to Enhance Cost-effective Emission Reductions and Low-carbon Investments, and Decision (EU) 2015/1814 [2018] OJ L 76/3 (Emissions Trading Directive).

37 Regulation (EU) 2018/842 on Binding Annual Greenhouse Gas Emission Reductions by Member States from 2021 to 2030 Contributing to Climate Action to Meet Commitments under the Paris Agreement and amending Regulation (EU) No 525/2013 [2018] OJ L 156/26 (Climate Action Regulation).

38 Regulation (EU) 2018/841 on the Inclusion of Greenhouse Gas Emissions and Removals from Land Use, Land Use Change and Forestry in the 2030 Climate and Energy Framework and amending Regulation (EU) No 525/2013 and Decision No 529/2013/EU [2018] OJ L 156/1 (Land Use, Land-Use Change and Forestry (LULUCF) Regulation).

3926 Oct. 2012 [2012] OJ C 326/391, available at: http://www.europarl.europa.eu/charter/pdf/text_en. pdf.

40 N. 28 above. 
What is particularly unique about Winter's analysis is that he serves as a member of the legal counsel representing the claimants, and offers this case analysis from an insider's perspective and prior to the European Court of Justice (ECJ) having taken a position on the merits of the case. The case, which was dismissed by the EU General Court in May 2019 on the grounds that the applicants lack standing, is currently pending appeal before the ECJ. Winter's analysis therefore offers a rare glimpse into the complex and layered arguments that the claimants are putting forward, as well as the actual and anticipated counter-arguments that the defendants have made and are likely to make. Given that this case - whether ultimately successful or not - both mirrors and anticipates other challenges of this kind in the EU and worldwide, the insight that Winter offers into the argumentation and strategy provides invaluable opportunities to inform similar cases as they develop and evolve worldwide. While the precise formulation of climate-based challenges to public and private actions and inactions will vary depending on the jurisdiction and the legal tools available for applicants to draw upon, the details Winter offers about how the claimants are formulating their claims, coping with complex questions of causation and legal attribution, and anticipating defences and legal obstacles, facilitate the precise form of transnational dialogue and iterative learning that TEL seeks to advance.

Together, the Symposium articles and Winter's case note illustrate the vibrancy and ingenuity that characterizes the realm of climate litigation, revealing it as an important site for legal innovation and experimentation.

\section{IMAGINING THE PARIS AGREEMENT AS A SITE FOR CONTINUING LEGAL INNOVATION}

The Carvalho case also reveals an important and unresolved intersection between international and national climate law. Among the many elements of the case that Winter unpacks is the claimants' proposal for how the EU should calculate its percentage of the global carbon emissions budget. It is only after calculating the EU's allowable share of global emissions, the claimants suggest, that the EU can adequately develop its climate law such that it is compliant with 'higher-ranking' law, including the Paris Agreement. ${ }^{41}$ As Winter reveals in his discussion of Carvalbo, the question of calculating domestic and regional budgets is a contentious and relatively unmapped area of law that implicates core questions of historic and current responsibility, social and economic capability, and justice and equity - matters that have formed the contentious and divisive heart of international climate negotiations from the start. ${ }^{42}$ The question

41 Winter, n. 27 above, pp. 141-55.

42 C. Voigt \& F. Ferreira, "Dynamic Differentiation”: The Principles of CBDR-RC, Progression and Highest Possible Ambition in the Paris Agreement' (2016) 5(2) Transnational Environmental Law, pp. 285-303; P. Cullet, 'Differential Treatment in Environmental Law: Addressing Critiques and Conceptualizing the Next Steps' (2016) 5(2) Transnational Environmental Law, pp. 305-28; P. Galvão Ferreira, “Common But Differentiated Responsibilities” in the National Courts: Lessons from Urgenda v. The Netherlands' (2016) 5(2) Transnational Environmental Law, pp. 329-51; L. Rajamani, 'The Principle of Common but Differentiated Responsibility and the Balance of 
of the EU's emissions budget forms a core piece of the argument in Carvalho that EU climate law is inadequate. The claimants suggest that the budget has not been properly calculated and propose methods for calculating it in order to ensure that EU climate law advances and complies with the global budget emanating from and advancing the $2{ }^{\circ} \mathrm{C}$ temperature increase limit established by the Paris Agreement. ${ }^{43}$ While in Carvalho the claimants engage with the question of emissions budgets, Winter suggests they ultimately shy away from engaging too deeply in what is inevitably a deeply political question. In his contribution, however, Alexander Zahar picks up and engages directly with the challenges that arise at the intersection between individual state and collective global ambition and obligation. ${ }^{44}$

Zahar's article deepens understanding of two of the most central but undertheorized questions in international climate change law, these being whether binding collective obligations exist in international climate change law and, relatedly, how collective obligations can be individualized to determine state-based obligations. Defining the shared goals and relative obligations of the international community and individual state actors is, of course, the crux of the climate challenge. Zahar provides a welcome and much needed intervention into this important but poorly mapped terrain. He starts by offering one of the first direct analyses of whether the Paris Agreement can and does create a legally binding collective obligation to keep global warming below $2^{\circ} \mathrm{C}$. Next, he advances thinking on how to go about 'resolv[ing] the global mitigation burden into state-level ambition commitments ${ }^{45}$ in order to ensure that state and collective obligations collectively advance the underlying objectives of the international regime.

Zahar frames his analysis by reminding readers of the centrality of a collective obligation to effectively address climate change, noting that ' $\mathrm{t}]$ hose who do not acknowledge the existence of a collective obligation in the treaty implicitly accept the possibility of a paradoxical result: each party ends up being legally compliant with the Paris Agreement's individual state obligations, thus rendering the Agreement a complete legal success, while at the same time global warming continues unabated and containment within the $2^{\circ} \mathrm{C}$ limit becomes impossible' ${ }^{46}$ In order to assess whether the Paris Agreement creates a genuine legal collective obligation, Zahar then engages with evolving thinking on state responsibility in international law to demonstrate that the concept of a collective obligation held by a community of states as a whole and owed to a community of states is conceptually possible. He nonetheless determines that while the parties to the Paris Agreement could have elected to create such an obligation, they failed to do so. Consequently, Zahar concludes that, while the Paris

Commitments under the Climate Regime' (2000) 9(2) Review of European Community \& International Environmental Law, pp. 120-31.

44 Zahar, n. 29 above.

45 Ibid., p. 165.

46 Ibid., p. 176. 
Agreement 'does create a collective obligation in form, [it] does not make it a legal obligation with legally binding force in substance'. 47

Even in aspirational form, however, the collective obligation the Paris Agreement establishes to hold the increase in the global average temperature below $2^{\circ} \mathrm{C}$ forms the essential core of international efforts to limit climate change. Finding a way to individuate this collective obligation is essential for ensuring that the Paris Agreement is legally meaningful and that the climate crisis is averted. Zahar engages with this challenge, working his way through the terms of the Agreement to determine where it creates collective and individual obligations and to assess whether mechanisms exist within the Agreement to facilitate the individuation of the mitigation burden. What Zahar's analysis reveals is one of the enduring and intractable weaknesses of international climate law: namely, the lack of a normative or instrumental framework for delegating individual state responsibility along metrics that are both equitable and effective. While the Paris Agreement fails to cure this flaw, Zahar suggests that the global stocktake process is 'sufficiently loose' and has been interpreted with 'sufficient ambiguity ... to enable the stocktake to take on the role of an individuation forum, should parties wish to use it for that purpose'. ${ }^{48}$

Zahar is not able to find the degree of legal innovation in the architecture of the Paris Agreement necessary to support the creation of a collective legal obligation or facilitate the individuation of obligations along settled metrics. His analysis, however, extends understanding of how the Paris Agreement creates categories of collective and individual obligations and provides a platform for further research on how these obligations can be transformed over time to advance state-level efforts and ambition.

\section{CONCLUSION}

In the dawning days of the new decade, there is much to mourn but also much from which to take heart. Even as fires rage and politics churn, there is an equal and opposite amount of energy fuelling new and creative efforts to resist legal erosion, counter environmental degradation, and advance transnational cooperation and innovation in response to the looming climate crisis. It is apt that the first issue of TEL in the new decade shines light on the plurality of thought and work that is taking place worldwide around climate change and offers hope that the rule of law remains a powerful tool in ongoing efforts to advance our shared future.

\section{TEL EDITORIAL BOARD DEVELOPMENTS}

The start of this new decade is also a time for 'hellos' and 'goodbyes' to several members of the TEL Advisory Board. It is with much gratitude that we say goodbye to parting members Ludwig Krämer, Ellen Hey, Stephen Humphreys, Edith Brown Weiss, Koh Kheng Lian, and Richard Revesz. Each of them has served on the Advisory Board

47 Ibid., p. 179.

48 Ibid., pp. 165 and 186. 
since the journal's inception, and their advice and support have been paramount in TEL's successes to date.

We are delighted that their footsteps, large as they are, will be filled by these outstanding new members: Daniel Bodansky, Jutta Brunnée, Jessica Green, Sébastien Jodoin, Jolene Lin, Leonie Reins, Joana Setzer, Katie Sykes, and Jonathan Verschuuren. Together with the other continuing members of the TEL Advisory Board and the entire Editorial Team, we extend the warmest of welcomes to each of these new colleagues, and we look forward to working with them to further develop TEL as we embark on the journal's second decade in existence.

Editors-in-Chief

Thijs Etty

Veerle Heyvaert

Editors

Cinnamon Carlarne

Bruce Huber

Jacqueline Peel

Josephine van Zeben 